\title{
CORRESPONDENCE
}

\section{THE RED SEA DEPRESSION}

SIR,--Professor Whiteman is to be congratulated for he has convincingly debunked the long held, tenaciously maintained and completely erroneous idea that the escarpments which bound the Red Sea are essentially fault or fault line scarps. I wholeheartedly support his contention that these are primarily downwarps modified by erosion, but would emphasize the presence of faulting, concomitant with the crustal flexuring. Furthermore, the dominant role of downwarping is indeed evident in the northern segment of the Ethiopian rift and particularly on the northern side of the Gulf of Aden where Upper Jurassic limestones are present in a series of $\mathrm{E}-\mathrm{W}$ fault blocks all tilted to the south at between $15^{\circ}$ and $25^{\circ}$ (Gass, Mallick \& Cox, 1965). This, in turn, is the result of a regional monoclinal flexure along the south coast of Arabia that appears to be diachronous, younging from east to west, possibly as the Gulf of Aden opened (Laughton, 1966).

Although I am in general agreement with what Professor Whiteman says, there are some minor points where we disagree and these I feel are worthy of mention:

(1) Whiteman (p.238) quotes a date of $148 \pm 30$ m.y. for the olivine dolerite sill at Khor Shinab, Sudan and credits me with a personal communication indicating a $25+$ m.y. age for this rock. So far as I am aware, both age determinations were carried out on specimens from the same locality. The age determined for me by Dr. N.J. Snelling, Mr. D. C. Rex and Mr. R. Goodwin of the Oxford Age Unit was 25.7 5 m.y. and was based on $\% \mathrm{~K}=0.082$ and ${ }^{40} \mathrm{Ar}=0.000151$ p.p.m. whereas the age quoted by Whiteman was based on $\% \mathrm{~K}=0.050$ and ${ }^{40} \mathrm{Ar}=0.00055$ p.p.m. As these basic intrusions occur in Middle Miocene sediments (Carella \& Scarpa, 1962; Sestini, 1965) and are petrographically similar, I cannot accept that basalts of widely varying age are present but suggest that the discrepancy lies in the age determinations, the Oxford age of $c .25 \mathrm{~m} . \mathrm{y}$. being the only one acceptable on the known stratigraphy of the area.

(2) On p.244 Whiteman notes that "from Mohr's recent work $(1967$, p.664-5) it appears that the central trough probably meets the continuation of the Wonji fault belt and its associated volcanoes in the islands of Jebel Tayr and Jebel Zubayr." There is no justification for this statement and it is so gross an oversimplification as to be completely untenable. The volcanic structures of Tayr (At Tair) and Zubayr (Zubair) are aligned in the direction of the central rift at c. $340^{\circ}$ and the rift continues as a bathymetric feature southwards before losing its identity in the shallow water that surrounds the volcanic islands of Jebel Zukur, Great and Little Hanish. These latter islands show a marked NE alignment (Gass, Mallick \& Cox, 1965).

(3) Quoting Girdler (1958) and Drake \& Girdler (1964), Whiteman reiterates that basic and ultrabasic rocks were intruded into the central rift. So far as I am aware, dredge hauls from the central rift have been of tholeiitic basalt (Chase, personal communication) whereas the active volcanic island of Tayr is certainly composed of tholeiitic basalts comparable in their major oxide chemistry to oceanic tholeiites such as the volcanic island of Hawaii. The basalt-trachybasalt-trachyandesite-trachyte associations of Zukur and the Hanish Group are markedly alkaline. No ultrabasic specimens have been recorded except on St. Johns Island which is, in all probability, a fragment of the Egyptian crystalline basement detached by faulting.

At the present state of published information, I am inclined to accept Whiteman's concluding statement that the crustal separation in the Red Sea must be limited to the width of the central trough (the intruded zone of Drake \& Girdler, 1964). I would, however, suggest that the downwarp margins to the Red Sea are probably the result of crustal attenuation that heralded the eventual crustal separation of the median rift and that the causative mechanism for both phenomena might well be the relative movement of the Arabian peninsula NE away from the Egypt-Sudan-North Ethiopian segment of the African continent.

\section{REFERENCES}

CARELLA, R. \& SCARPA, N. 1962. Geological results of exploration in Sudan by A.G.I.P. Mineraria Ltd. 4th Arab Petroleum Congress (Beirut). 
DRAKE, C. L. \& GIRDLER, R. W. 1964. A geophysical study of the Red Sea. Geophys. $J$. R. astr. Soc., $8(5), 473-495$.

GASS, I. G., MALLICK, D. I. J. \& COX, K. G. 1965. Royal Society volcanological expedition to the South Arabian Federation and the Red Sea. Nature, Lond., 205 (4975), 952-955.

GIRDLER, R. W. 1958. Geophysical studies of rift valleys. $Q$. Jl geol. Soc. Lond., $144,79-105$.

LAUGHTON, A. C. 1966. The Gulf of Aden. Phil. Trans. R. Soc., A, 259, 150-171.

MOHR, P. A. 1967. Major volcano-tectonic lineaments in the Ethiopian rift system. Nature, Lond., 213 (5177), 664-5.

SESTINI, J. 1965. Cenozoic stratigraphy and depositional history, Red Sea coast, Sudan. Bull. Am. Ass. Petrol. Geol., 49 (9), 1453-1472.

\section{DEPARTMENT OF EARTH SCIENCES, THE UNIVERSITY, LEEDS 2. \\ Ist August, 1968.}

SIR,-Dr. I. G. Gass' rejection on stratigraphic grounds of Geochron Laboratories potassium-argon date $148 \pm 30 \mathrm{~m} . y$. in favour of the Oxford Age Unit date of $25.7 \pm 5 \mathrm{~m} . \mathrm{y}$. is not acceptable because only the strata above the Khor Shinab flow have been dated by fossils.

Carella \& Scarpa (1962) reported a fauna indicating a Middle Miocene (Helvetian) age for the Abu Imama formation which overlies the flow, but the underlying formation was assigned to the Maghersum formation simply on lithological grounds. Therefore the flow and underlying strata could be older than Miocene, especially as the Mukawwar formation which outcrops nearby has been dated paiaeontologically as "Cretaceous transitional to Paleocene." A Jurassic, or at the latest an Early Cretaceous, age for the Khor Shinab basalt analysed by Geochron Laboratories is a possibility, but clearly more work is needed in the area to provide a satisfactory solution because the specimens appear to have been collected from different parts of a continuous outcrop.

I am particularly grateful to Dr. Gass for drawing attention to the tholeiitic basalts reported in dredge hauls by Chase, and for commenting on the relationship of the Wonji fault belt and the central volcanic islands.

\section{DEPARTMENT OF GEOLOGY, \\ UNIVERSITY OF IBADAN, NIGERIA.}

29 th October, 1968.

\section{THE AGE OF THE OLDEST SILURIAN BEDS OF THE RUMNEY (CARDIFF) INLIER}

SIR,-During the course of stratigraphical and palaeontological studies in the Silurian of the Welsh Borderland and South Wales I have encountered some conflicting opinions in the literature regarding the age of the beds of the Rumney (Cardiff) inlier. Confusion appears to have arisen in the past as a result of the mis-identification of fossils, but now a reinvestigation of the faunas, combined with detailed mapping, allows the age of the oldest beds in the inlier to be firmly established. The mapping of the area is still in progress, but as a number of co-workers in the Silurian are engaged in problems of correlation and palaeogeographical reconstruction the preliminary results are considered to be of sufficient interest to warrant early publication.

The presence of Silurian rocks at Cardiff was first recorded by Glass $(1861$, p.168) who submitted a collection of fossils to Murchison and Salter for identification. Murchison 